\title{
MICROBIAL BIOMASS AND ACTIVITY IN LITTER DURING THE INITIAL DEVELOPMENT OF PURE AND MIXED PLANTATIONS OF Eucalyptus grandis AND Acacia mangium ${ }^{(1)}$
}

\author{
Daniel Bini ${ }^{(2)}$, Aline Fernandes Figueiredo ${ }^{(3)}$, Mylenne Cacciolari Pinheiro da Silva ${ }^{(4)}$, \\ Rafael Leandro de Figueiredo Vasconcellos ${ }^{(5)}$ \& Elke Jurandy Bran Nogueira Cardoso ${ }^{(6)}$
}

\begin{abstract}
SUMMARY
Studies on microbial activity and biomass in forestry plantations often overlook the role of litter, typically focusing instead on soil nutrient contents to explain plant and microorganism development. However, since the litter is a significant source of recycled nutrients that affect nutrient dynamics in the soil, litter composition may be more strongly correlated with forest growth and development than soil nutrient contents. This study aimed to test this hypothesis by examining correlations between soil $C, N$, and $P$; litter $C, N, P$, lignin content, and polyphenol content; and microbial biomass and activity in pure and mixed second-rotation plantations of Eucalyptus grandis and Acacia mangium before and after senescent leaf drop. The numbers of cultivable fungi and bacteria were also estimated. All properties were correlated with litter C, N, P, lignin and polyphenols, and with soil $\mathrm{C}$ and $\mathrm{N}$. We found higher microbial activity $\mathrm{CCO}_{2}$ evolution) in litter than in soil. In the $\boldsymbol{E}$. grandis monoculture before senescent leaf drop, microbial biomass $\mathrm{C}$ was $46 \%$ higher in litter than in soil. After leaf drop, this difference decreased to $16 \%$. In A. mangium plantations, however, microbial biomass $C$ was lower in litter than in soil both before and after leaf drop. Microbial biomass $\mathrm{N}$ of litter was approximately $94 \%$ greater than that of the soil in summer and winter in all plantations. The number of cultivable fungi and bacteria increased after leaf drop, especially so in the litter. Fungi were also more abundant in the $E$. grandis litter. In general, the $A$. mangium
\end{abstract}

\footnotetext{
(1) Part of doctoral degree thesis of the first author by the Post-Graduation Program in Soils and Plant Nutrition, University of São Paulo, ESALQ. Department of Soil Science. Av. Pádua Dias, 11, CEP 13418-900 Piracicaba (SP), Brazil. Received for publication on July 03, 2012 and approved on November 20, 2012.

(2) Doctor degree in Soils and Plant Nutrition. University of São Paulo, ESALQ. E-mail: dani_bini@yahoo.com.br.

(3) Graduate student on Environmental Engineering, Engineering School of Piracicaba, EEP. E-mail: lineffigueiredo@hotmail.com.

(4) Doctor degree in Agricultural Microbiology. University of São Paulo, ESALQ. E-mail: mylennepi@gmail.com

(5) Doctor in Soils and Plant Nutrition, University of São Paulo, ESALQ. E-mail: rafaellfvas@yahoo.com.br

(6) Full Professor, University of São Paulo, ESALQ, Departament of Soil Science. E-mail: ejbncard@.usp.br
} 
monoculture was associated with higher levels of litter lignin and $N$, especially after leaf drop. In contrast, the polyphenol and $\mathrm{C}$ levels in $\boldsymbol{E}$. grandis monoculture litter were higher after leaf drop. These properties were negatively correlated with total soil $\mathrm{C}$ and $\mathrm{N}$. Litter in the mixed stands had lower $\mathrm{C}: \mathrm{N}$ and $\mathrm{C}: \mathrm{P}$ ratios and higher $\mathrm{N}, \mathrm{P}$, and $\mathrm{C}$ levels in the microbial biomass. This suggests more effective nutrient cycling in mixed plantations in the long term, greater stimulation of microbial activity in litter and soil, and a more sustainable system in general.

Index terms: microorganism, litterfall, bioindicators, forestry, legumes, basal respiration.

\section{RESUMO: BIOMASSA E ATIVIDADE MICROBIANA DA SERAPILHEIRA DURANTE O DESENVOLVIMENTO INICIAL DE PLANTIOS PUROS E MISTOS DE Eucalyptus grandis $E$ Acacia mangium}

A serapilheira é, muitas vezes, um compartimento negligenciado para avaliação e melhor entendimento do comportamento da atividade e biomassa microbiana em plantios florestais. Quase sempre, em estudos dessa natureza, os autores tentam encontrar explicações para o padrão de desenvolvimento de plantas e microrganismos, por meio da avaliação dos nutrientes minerais no solo. Entretanto, considerando-se a dinâmica de disponibilização desses nutrientes, a hipótese é que provavelmente ocorra maior relação entre o crescimento de plantas florestais e da atividade microbiana com os nutrientes presentes na serapilheira. Este estudo teve como objetivo avaliar a atividade e biomassa microbiana e o número mais provável de fungos e bactérias totais cultiváveis do solo e da serapilheira, numa segunda rotação de plantios puros e mistos de Eucalyptus grandis $e$ Acacia mangium, manejados em cultivo mínimo, antes e após a deposição de folhas senescentes. Esses atributos foram relacionados com os teores totais de $C, N$, $P$ e teor de lignina e polifenóis da serapilheira e $C, N$ e $P$ do solo. Antes da deposição de folhas senescentes, o $C$ da biomassa microbiana da serapilheira foi $46 \%$ maior que a biomassa microbiana do solo nos plantios de E. grandis. Após a deposição foliar, essa diferença diminuiu para $16 \%$. No entanto, o C da biomassa microbiana da serapilheira no plantio puro de A. mangium foi menor que qualquer um desses valores. Já o $N$ da biomassa microbiana da serapilheira apresentou-se com grande potencial para estocar esse nutriente, sendo, em média, $94 \%$ maior que o $N$ da biomassa microbiana do solo nas duas épocas e em todos os plantios. Houve maior atividade microbiana na serapilheira que no solo. Além disso, o plantio misto e a monocultura de E. grandis com $N$ apresentaram maior atividade microbiana, após a deposição foliar. O número mais provável de fungos e bactérias totais cultiváveis foi maior após a deposição, com maior representação na serapilheira; os fungos foram mais relacionados com os resíduos de $E$. grandis. De maneira geral, o plantio puro de A. mangium foi mais relacionado com altos teores de lignina e $N$ na serapilheira, principalmente após a deposição foliar. Diferentemente, as monoculturas de E. grandis sempre tiveram relação com os maiores teores de C da serapilheira e de fenóis totais, após a deposição foliar, sendo negativamente relacionadas com os teores de $C$ e $N$ totais do solo. $O$ plantio consorciado promoveu na serapilheira menores relações $C: N$ e $C: P$ e maiores teores de $N, P$ e $C$ da biomassa microbiana, sobretudo após a deposição foliar, o que demonstra a dinâmica desse compartimento. Esse fato pode favorecer melhor ciclagem de nutrientes em longo prazo, com estímulo à atividade microbiana do solo e da serapilheira e à sustentabilidade desse sistema de plantio.

Termos de indexação: microrganismos, liteira, bioindicadores, floresta, leguminosas, respirometria. 


\section{INTRODUCTION}

Eucalyptus is the most widely planted tree in reforestation projects in Brazil, where the species is currently grown on several different soil types. Most of these soils are acidic and nutrient-poor (Gonçalves et al., 2002; Araújo et al., 2004). Fertilizing eucalyptus plantations to maintain production levels is prohibitively expensive, and once the trees form a closed canopy, responses to fertilization are weak or absent (Gonçalves et al., 2004), since at this stage, the trees depend heavily on biogeochemical cycling. $\mathrm{C}, \mathrm{N}$, and $\mathrm{P}$ cycling are associated with organic matter, i.e., managing plantations to preserve high-quality plant residues improves nutrient cycling and sustainability (Gonçalves et al., 2004).

Intercropping with leguminous plants helps increase the sustainability of forestry plantations, since with an adequate management, it can increase timber production. Intercropped plantations in which Lupinus sp. or Lotus sp. are grown with Pinus radiata were studied in New Zealand and Australia (West et al., 1991). More recently, plantations with Acacia sp. and Eucalyptus sp. have been studied in Australia and Brazil (Forrester et al., 2006; Bouillet et al., 2008; Laclau et al., 2008; Nouvellon et al., 2012). These authors reported promising early results from a mixed plantation of $E$. grandis and A. mangium for aspects such as tree growth, plant biomass, root development, efficiency of biological $\mathrm{N}$ fixation, litter deposition, and other benefits. Planting eucalyptus in association with leguminous plants can improve soil nutrition due to the fixation of atmospheric $\mathrm{N}_{2}$ and the deposition of leaves with a high $\mathrm{N}$ content, which can return to plants after decomposition (Bouillet et al., 2008; Voigtlaender et al., 2012). In this case, additional information on the chemical and microbiological composition of litter can improve the understanding of intercropped systems, especially during the plant establishment phase, by analyzing the dynamics of this critical compartment for biogeochemical cycling (Gonçalves et al., 2004; Barreto et al., 2008).

Litter serves as a physical barrier against erosive processes and as a nutrient pool. Its decomposition speed is closely related to the $\mathrm{C}: \mathrm{N}$ ratio and its microbial community, which facilitate processes of decomposition and mineralization (Gama-Rodriguez, 1997). High levels of lignin, polyphenols, and cellulose may slow down the litter decomposition, resulting in lower levels of soil-available nutrients (Swift et al., 1979). Senescent leaf drop and/or a permanent litter cover on the ground appear to be two of the main pathways by which $\mathrm{C}$ and nutrients are returned to soils. Soil fauna and microorganisms initiate the process of breaking down the litter before it comes into direct contact with soils. Gama-Rodrigues et al. (2008) and Barreto et al. (2008) observed that the microbial biomass $\mathrm{C}$ and $\mathrm{N}$ of litter represent important $\mathrm{C}$ and $\mathrm{N}$ pools in eucalyptus plantations, since microbial activity is often related to $\mathrm{C}, \mathrm{N}$, lignin, and phenol concentrations in litter.

In general, decomposition occurs after the release of enzymes and organic acids that mineralize organic matter and make mineral compounds available for plants and other soil organisms (Badiane et al., 2001). In this case, maintaining high-quality organic matter in plantations is crucial for activating the soil microbiota, since their activity and biomass are more effective indices of $\mathrm{C}, \mathrm{N}$, and $\mathrm{P}$ dynamics and of soil health than soil chemistry (Dick \& Tabatabai, 1993; Monteiro \& Gama-Rodriguez, 2004). The microbial biomass represents the labile fraction of soil organic matter. Because it is highly dynamic and sensitive to soil management-related disturbances, it is widely used as an indicator of soil quality (Nogueira et al., 2006; Kaschuk et al., 2010). Senescent leaf drop can modify microbial biomass and activity, as can the presence of total fungi and bacteria in the soil or litter. The objective of this study was to assess the dynamics of chemical and microbiological properties of soil and litter before and after leaf drop in pure and mixed plantations of $E$. grandis and A. mangium.

\section{MATERIALS AND METHODS}

The study was carried out at the Experimental Station of Forestry Sciences Itatinga, which is administered by the Forestry Sciences Department of the "Luiz de Queiroz" School of Agriculture and located in Itatinga, São Paulo State, Brazil $\left(23^{\circ} 02^{\prime}\right.$ $01^{\prime \prime} \mathrm{S} 48^{\circ} 37^{\prime} 30^{\prime \prime} \mathrm{W}$, on average $830 \mathrm{~m}$ asl). June and July are the coldest, driest months (monthly means of $16{ }^{\circ} \mathrm{C}$ and $45 \mathrm{~mm}$, respectively), while December and January are the warmest and rainiest $\left(24^{\circ} \mathrm{C}\right.$ and $360 \mathrm{~mm}$ ). The soil in the study area is classified as Ferralsol (FAO classification), with $84 \%$ sand and $12 \%$ clay. After the first harvest rotation, the soil contained $23 \mathrm{~g}$ of organic matter and had a CEC of 11 $\mathrm{mmol}_{\mathrm{c}} \mathrm{kg}^{-1}$.

The experiment was carried out in an area of a former plantation of Eucalyptus saligna, maintained as a coppice without fertilizers (1940-1998). After the vegetation was removed, a plantation of $E$. grandis was established with low levels of fertilization (300 kg ha-1 of NPK 10:20:10), and the trees were harvested in December 2002. After a short rest period, a first rotation of pure and mixed plantations of $E$. grandis and Acacia mangium was established in randomized blocks in May 2003. The trees were harvested in May 2009. Of the 30 x $30 \mathrm{~m}$ plots, only the central $18 \times 18 \mathrm{~m}$ of each one were evaluated in the study and the borders disregarded. A more detailed description of the experimental design was provided by Laclau et al. (2008).

This study took place at the beginning of a second rotation of pure and mixed plantations of $E$. grandis 
and $A$. mangium, initiated in November 2009. The same experimental design as in the first rotation was used, with no till management, arranged in three randomized blocks with five treatments: $(\mathrm{E})$ monocultures of $E$. grandis (100E:0A) and (A) A. mangium (0E:100A) without $\mathrm{N}$ fertilizer; (EN) a monoculture of $E$. grandis (100E:0A) with $\mathrm{N}$ fertilizer $\left(120 \mathrm{~kg} \mathrm{ha}^{-1} \mathrm{~N}\right)$ in the form of ammonium sulfate applied at the beginning of the plantation (in holes beside the seedlings) and from then on every six months and a mixed plantation of $E$. grandis and $A$. mangium (50A:50E) without $\mathrm{N}$ fertilizer. The mixed plantation was subdivided so that soil could be sampled at the stem base of individual A. mangium (CA) and $E$. grandis (CE) trees, in order to assess any possible changes in the regions affected by the roots and litter of each species within the treatment.

Soil samples were collected from the $0-10 \mathrm{~cm}$ layer in two periods: July and December 2010 (i.e., seven and 14 months after tree planting). Nine representative trees per plot were chosen and three soil subsamples collected from three different places near the base of each tree (between rows and up to 1.5 $\mathrm{m}$ from the trunk). Nine independent subsamples (one per tree) were mixed to form a composite sample. From each plot in the monocultures three composite samples were formed, and six per plot in the mixed plantations (three from $E$. grandis and three from A. mangium). Thus, nine composite samples were formed per treatment and sampling period.

Litter samples were collected with a $0.25-\mathrm{m}^{2}$ quadrat using the same strategy as for soil sampling. Seven months after planting, litter consisted of dry plant waste, while 14 months after planting it also included senescent leaves. Litter samples were ovendried at $45{ }^{\circ} \mathrm{C}$ and weighed to estimate mass. Airdried soils were used for soil chemical analyses.

Total $\mathrm{C}$ and $\mathrm{N}$ of litter and soil were quantified in an elemental analyzer. Total $\mathrm{P}$ in litter was quantified according to Murphy \& Riley (1962). The total C, N, and $\mathrm{P}$ litter contents were adjusted based on ash content analysis after ignition at $550^{\circ} \mathrm{C}$ to constant weight (Anderson \& Ingram, 1996). Total phenols were determined using Folin-Denis reagent in a basic medium, using tannic acid standard, after which they were read in a spectrophotometer at a wavelength of 760 ๆm (Anderson \& Ingram, 1996). The lignin litter content was quantified using the acid detergent fiber method of van Soest \& Wine (1968). Microbial biomass $\mathrm{C}$ and $\mathrm{N}$ of soil (MBCSO and MBNSO) and litter (MBCLI and MBNLI) were obtained by fumigationextraction following Vance et al. (1987) and determined based on Gama-Rodriguez et al. (2008). The accumulated respiration of the soil microbiota (ARSO) and of the litter microbiota (ARLI) was measured as proposed by Alef (1995), with incubation of up to 21 days of $4 \mathrm{~g}$ of litter and $100 \mathrm{~g}$ of soil. The most probable numbers (MPN) of heterotrophic bacteria and cultivable fungi were estimated by the drop method
(Jahnel et al., 1999), using Nutrient Agar and Martin's media, respectively.

Data were subjected to analysis of variance and Duncan's and Dunnett's mean tests at $5 \%$ level. Chemical and microbiological properties of soil and litter were explored with principal component analysis (PCA) to identify values of properties associated with the areas during the two harvest periods. The PCA was performed with Canoco for Windows 4.5 (Ter Braak \& Smilauer, 2002).

\section{RESULTS AND DISCUSSION}

\section{Litter and microbial activity}

In all treatments, microbial activity was higher in litter than in soil (Table 1). This result mirrors that of Carvalho et al. (2008), who reported higher levels of microbial activity in the litter of Pinus elliottii than in the soils of the same stand, due to higher nutrient and $\mathrm{C}$ availability in the litter. In our study, seven months after planting, the ARSO in CE and $\mathrm{CA}$ accounted for approximately $6.5 \%$ of all $\mathrm{CO}_{2}$ emissions, and ARLI for the rest. After 14 months, ARSO and ARLI were highest in CA, CE, and EN (Figure 1). In those areas, approximately $24 \%$ of the $\mathrm{CO}_{2}$ emissions were due to ARSO. Comparable numbers for $\mathrm{A}$ and $\mathrm{E}$ were $30 \%$ (Figure 1). In this case, more extensive root development and senescent leaf drop may have additionally stimulated the soil microbial activity, since the rainy season and more advanced plant development are important factors for microbial development and metabolism (Sinha et al., 2009). Although ARSO increased from seven to 14 months, the differences between plantations were more striking for ARLI (Figure 1). This could be the result of a greater accumulation of senescent leaves, which stimulate microbial activity in the litter according to the kind of litter fall and the remaining litter from the first rotation. The mixture of two species (CA and $\mathrm{CE}$ ) may have resulted in waste that was more easily broken down, generating litter with higher $\mathrm{N}$ and $\mathrm{P}$ contents and lower C:N and C:P ratios (Table 1), and thereby stimulating the microbiota and nutrient cycling (Andersson et al., 2004). The microbial degradation of this mixed litter was similar to that of $\mathrm{EN}$, suggesting that the presence of mineral $\mathrm{N}$ from fertilizer and of organic $\mathrm{N}$ derived from legumes at the $E$. grandis site can stimulate microbial activity in the litter.

\section{Lignin and polyphenol content of litter}

Although the trees were well-developed seven months after planting, senescent leaves had not yet begun to fall. As a result, the litter composition was mainly influenced by the material deposited in the previous rotation, which by that time was mostly dry. In this sampling period, more litter had accumulated 
in the mixed plantations, due to the mixture of waste material from the two species and the lower decomposition rate by the soil microbiota (Table 1 and Figure 1). Smith \& Bradford (2003) noted that a mixture of wastes can have a negative effect on litter decomposition, largely by changing the soil microbial community. In our study, however, microbial activity in the litter was stimulated following leaf drop 14 months after planting (Figure 1). This stimulus could be the result of senescent leaves, which helped break down and decrease the total mass of the dry material already present in the litter. Fresh leaf waste provides

Table 1. Chemical analysis of litter in different treatments seven and 14 months after planting: dry matter (DM), nitrogen (N), carbon (C), phosphorus (P), C:N and C:P ratios, content of lignin (LIG) and total phenols (TPH), LIG:N ratio, TPH:N ratio, carbon microbial (MBC):C ratio, nitrogen microbial (NBM):N ratio

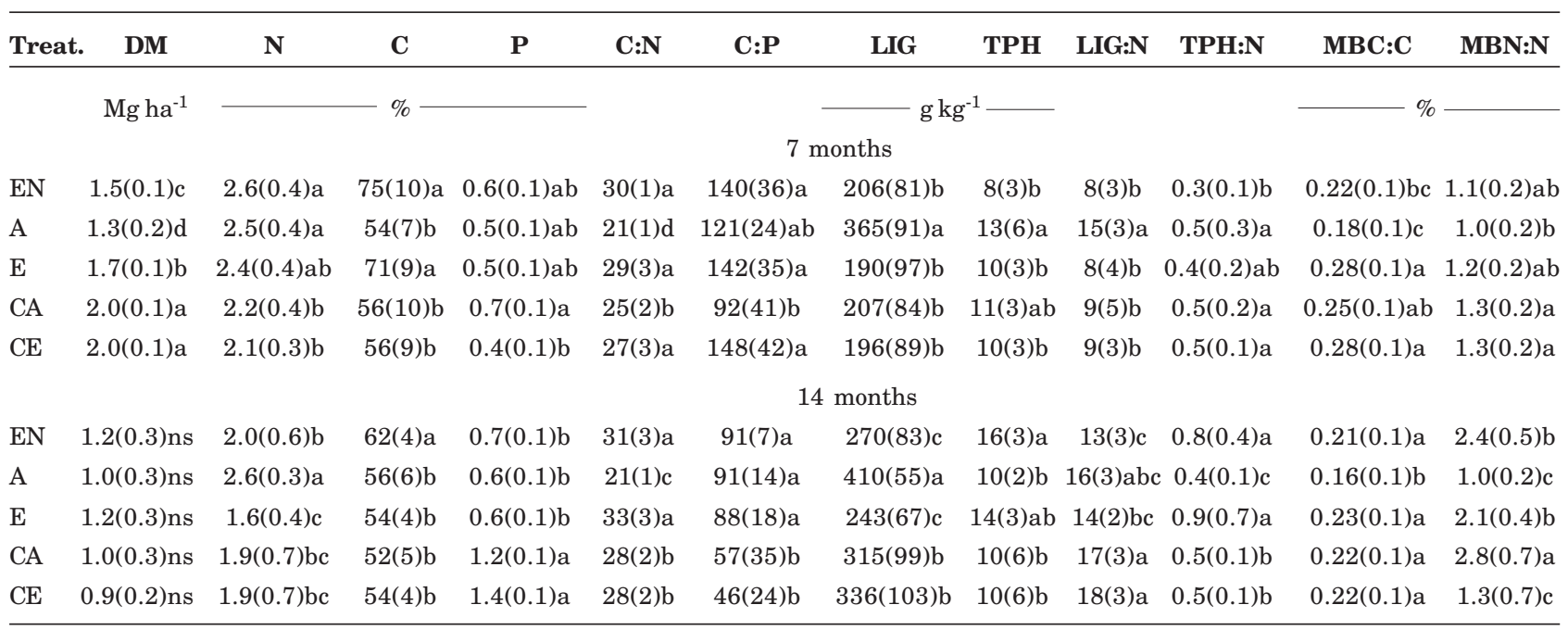

Treat.: treatment; (A) A. mangium monoculture; (E) E. grandis monoculture; (EN) E. grandis monoculture with nitrogen fertilizer; (CA) mixed plantation (at the base of A. mangium); (CE) mixed plantation (at the base of $E$. grandis). Values followed by the same letter within a column are not significantly different according to Duncan's test at $5 \%$; mean standard deviations in parentheses.

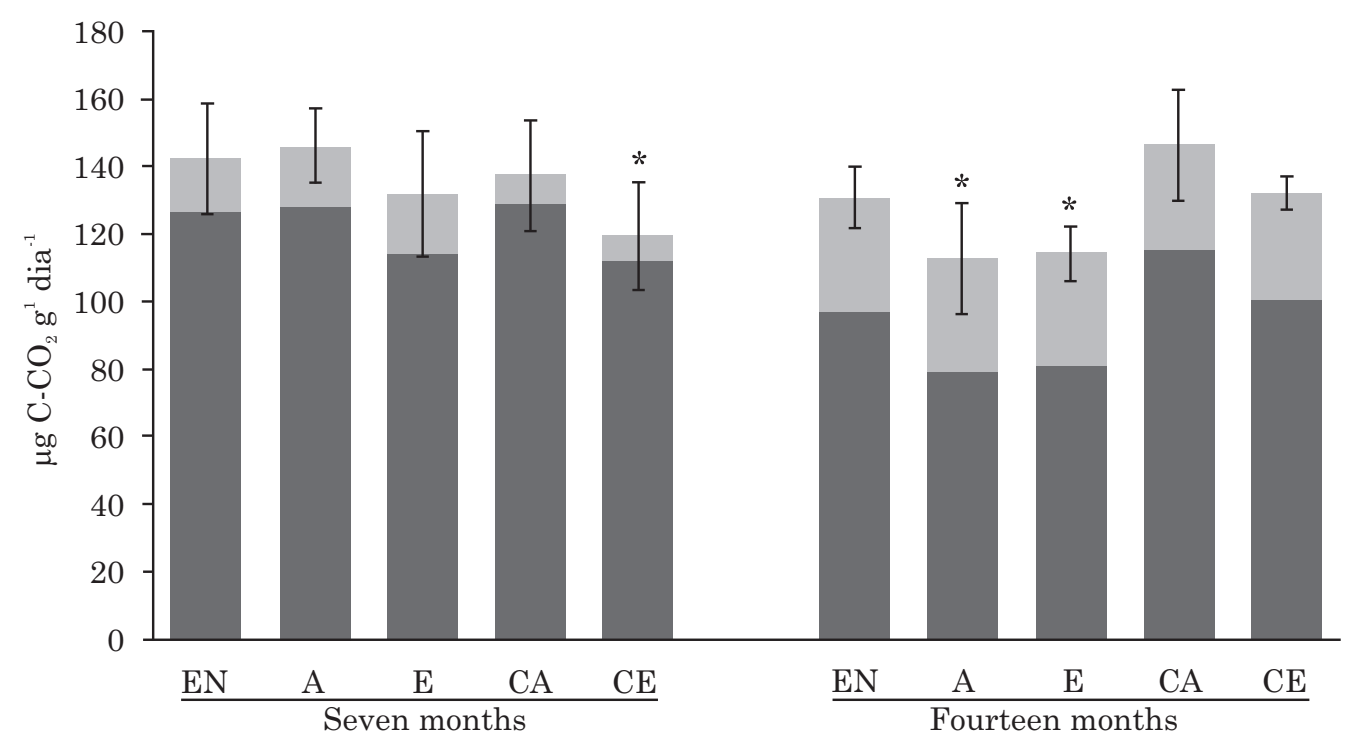

Figure 1. Daily $\mathrm{CO}_{2}$ release by microbial respiration from the two compartments of the study: litter (dark gray) and soils (light gray), seven and 14 months after planting. (A) A. mangium monoculture; (E) $E$. grandis monoculture; (EN) $E$. grandis monoculture with $\mathrm{N}$ fertilizer; (CA) mixed plantation (measured at the stem base of $A$. mangium); (CE) mixed plantation (measured at the stem base of $E$. grandis). (*) indicate a statistical difference from the EN treatment according to Duncan's test at a $5 \%$. 
more immediately mineralizable compounds than older, more decomposed leaf waste (Carvalho et al., 2008).

Although the C:N and C:P ratios of litter are good indicators of the residue quality in the early stages of decomposition (Taylor et al., 1989; Hector et al., 2000; Smith \& Bradford, 2003), it is important to note that each plant species generates a unique kind of waste, such that differences in $\mathrm{N}$ contents may not be the only properties that affect the litter quality and decomposition. Other characteristics, such as lignin or total phenol content, may offset the positive effect of mixed waste (Hector et al., 2000; Smith \& Bradford, 2003), altering the microbial activity and biomass of soil and litter (Monteiro et al., 2004).

Higher lignin concentrations were found in A in both sampling periods (Table 1 ). According to Knorr et al. (2005), litter quality can be classified based on the lignin concentration $(<10 \%=$ high quality, $10-20 \%=$ moderate quality, $>20 \%=$ low quality). By this classification, the waste quality of monocultures and mixed plantations was low (concentrations $>20 \%$ ). However, A had the lowest-quality waste, according to the lignin concentration (37 and $41 \%$ after seven and 14 months, respectively). A. mangium waste may be less susceptible to rapid decomposition due to a greater lignin quantity (more fibrous material, despite higher $\mathrm{N}$ levels). This characteristic of $A$. mangium waste changed when intercropped with $E$. grandis, where the lignin proportion in residues was reduced ( 21 and $32 \%$ after seven and 14 months, respectively). This indicates that intercropping the two species improves litter quality by reducing lignin content and $\mathrm{C}: \mathrm{N}$ and C:P ratios. In the mixed plantation, especially after leaf drop, $\mathrm{CA}$ and $\mathrm{CE}$ showed intermediate lignin concentrations and TPH:N ratios and higher TPH:N ratios (Table 1) that did not differ from those of $\mathrm{A}$. The smaller the TPH:N and LIG:N ratios, the easier it is for the microbiota to access and release $\mathrm{N}$ in the litter (Swift, 1979; Monteiro et al., 2004).

Polyphenols are known to play a key role in regulating the levels of available nutrients in litter, since they defend plants against pathogens and decomposers and partly regulate the access of decomposing microorganisms to residues (Levin, 1971). The greater quantity of total phenols and lignin may result in a greater litter humification, helping retain and conserve soil nutrients, which could be beneficial to the system in the long term. For this reason, the conditions of mixed-plantation litter were better for microbial activity than in the monocultures, due to the positive aspects of the two tree species (low $\mathrm{C}: \mathrm{N}$ and $\mathrm{C}: \mathrm{P}$ ratios, higher $\mathrm{P}$ content, and intermediate lignin concentrations and TPH: $\mathrm{N}$ ratios). These results are interesting, since these characteristics can potentially modulate microbial activity in soils and litter, boosting the efficiency of nutrient cycling during decomposition and favoring humification by the presence of phenolic compounds and lignin (Prescott, 2010).

\section{Microbial biomass in soil and litter}

Seven months after the trees were planted, MBCSO and MBNSO were highest in CA and CE, together with A and EN (Figure 2). After leaf drop (14 months after planting), MBCSO and MBNSO had increased in all treatments. The highest values were found in $\mathrm{A}$, and high MBCSO was also found in CA (Figure 2). MBCSO was neither stimulated nor suppressed in the mixed plantation, where values for individual trees were similar to those observed in the monocultures. This was not the case, however, for MBNSO, which decreased for $A$. mangium in the presence of $E$. grandis (Figure 2). This shows that plant development and leaf drop altered the microbial biomass, and a new equilibrium could have been established (Andersson et al., 2004; Sinha et al., 2009). What is clear is that the input of $\mathrm{C}$ and nutrients into the system differed strongly between the two sampling periods, and that these differences caused changes in the soil microbiota, by suppression and/or stimulus of microbial biomass and activity in the mixed plantation due to the presence of both species.

In contrast to the results observed in soil, MBCLI decreased with increasing plant development and leaf drop in all plantations (Figure 2). The presence of $E$. grandis waste may be related to the greater MBCLI content, even in the intercropped plantation. In contrast, MBNLI in EN and CA was approximately twice as high as in A, CE, and E, 14 months after planting (Figure 2). Although these differences were confirmed, the $\mathrm{N}$ pool of MBNLI at these latter sites was still considerable. Norby \& Cotrufo (1998) argued that the immobilization of $\mathrm{N}$ by the microbial biomass is a temporary phenomenon and may be a good indicator of the fertility of the system. Likewise, Monteiro \& Gama-Rodrigues (2004) and GamaRodrigues et al. (2008) suggested that the microbial biomass in litter could represent an important pool of $\mathrm{C}$ and nutrients, since values observed in eucalyptus litter are higher than those found in soils (GamaRodrigues, 1997; Barreto et al., 2008).

In studies on eucalyptus, Gama-Rodriguez et al. (2008) found that MBCLI was at least 6-7 times higher than MBCSO. In this study, MBCLI was higher than MBCSO in areas with $E$. grandis (E, EN, CA, and $\mathrm{CE}$ ), but not in the A. mangium monoculture (A). Differences between MBCLI and MBCSO also declined after leaf drop. Seven months after planting, MBCLI was on average $46 \%$ higher than MBCSO in areas with $E$. grandis, but after 14 months this had decreased to $16 \%$. MBNLI was 96 and $92 \%$ higher than MBNSO seven and 14 months after planting, respectively. In the plantations, the $\mathrm{N}$ stocks in the microbial biomass of the litter represented a large pool of $\mathrm{N}$, especially given the low values of MBNSO. Indeed, differences between the treatments at the beginning of leaf drop are important to identify which treatment can help maintain and increase microbial biomass in soil and litter, and which changes take place in those compartments as plants develop. 

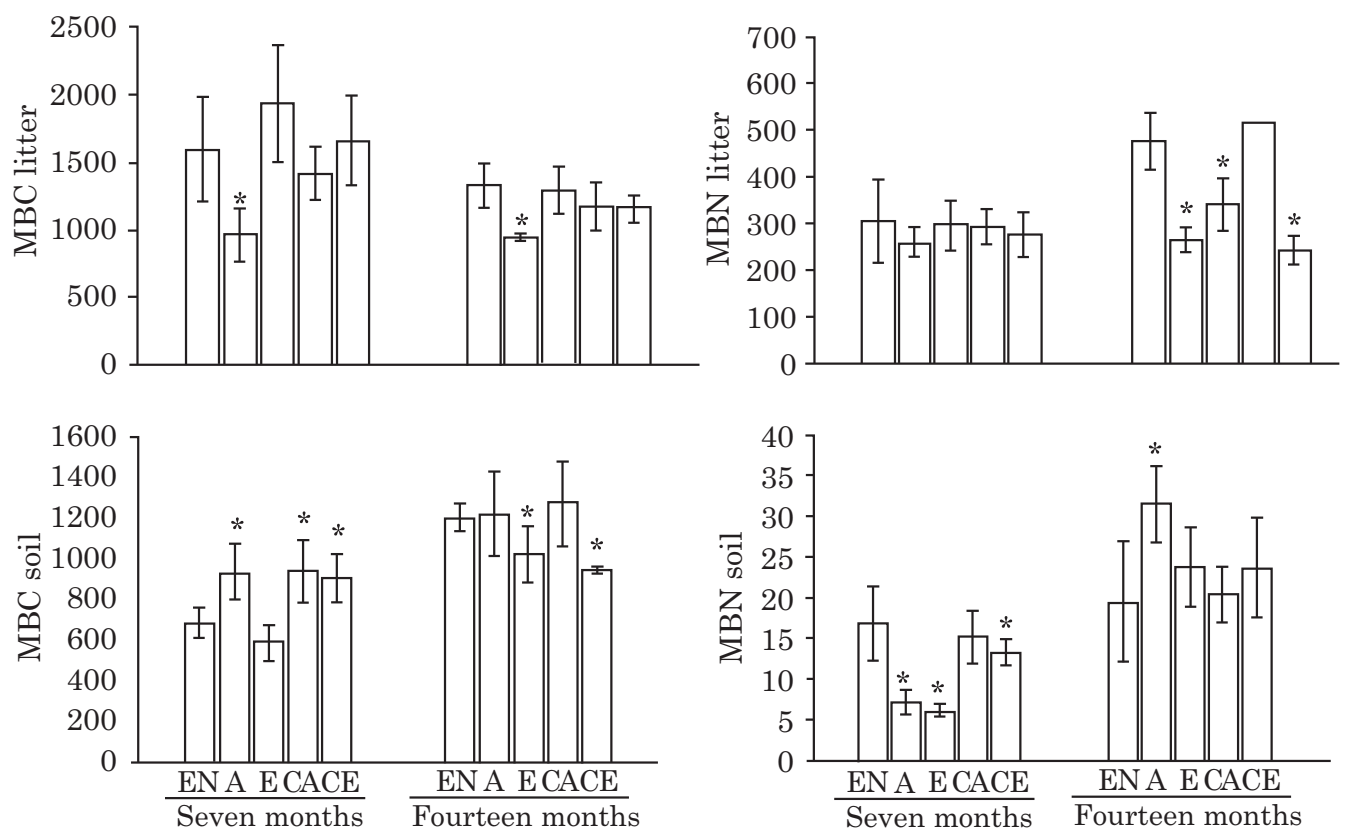

Figure 2. Microbial biomass carbon (MBC) and nitrogen (MBN) of soil and litter seven and 14 months after planting. (A) A. mangium monoculture; (E) E. grandis monoculture; (EN) E. grandis monoculture with $\mathrm{N}$ fertilizer; (CA) mixed plantation (at the stem base of $A$. mangium); (CE) mixed plantation (at the stem base of $E$. grandis). (*) indicate a statistical difference from the EN treatment according to Duncan's test at a $5 \%$.

\section{Multivariate data analyses}

The principal component analysis (PCA) revealed patterns in the chemical and microbiological properties of soil and litter between the monocultures and intercropped plantations for the two sampling periods (Figure 3). After seven months, $42.9 \%$ of the variation in the data was explained by Axis 1 and $36.0 \%$ by Axis 2 (Figure 3a). The variables ARSO, MBCLI, MBNSO, and lignin content accounted for most of the variation in the data seven months after planting. In this period, the $E$. grandis monocultures (EN and E) could be found close to the factorial plane, with a stronger association with total litter $\mathrm{C}$ and a negative relationship with total $\mathrm{N}$ and $\mathrm{C}$ in soil and MBCSO. The CA and CE treatments were more closely associated with dry litter and MBNSO, indicating that the intercropped plantation can induce larger nitrogen stocks in soils via the microbial biomass, which is advantageous for the system (Norby \& Cotrufo, 1998).

After leaf drop (14 months after planting), the relationships of some chemical and microbiological properties of soil and litter changed at the different sites (Figure 3b). After 14 months, Axis 1 accounted for $47.8 \%$ and Axis 2 for $19.3 \%$ of variation (Figure $3 \mathrm{~b})$. The proximity of the eucalyptus monocultures (EN and E) on the factorial plane after 14 months may be explained by a stronger association of those areas with MBCLI, total litter C, and total phenol content. In general, polyphenols are broken down by fungi (Auer et al., 2007). The greater presence of fungi in these wastes could be attributed to the greater
MBCLI, since fungi represent approximately $70 \%$ of the total microbial biomass (Brandão, 1997). To this we must add the greater stimulus of total cultivable bacteria in litter in EA and EN after 14 months (Table 2 ), which could indicate that the $\mathrm{N}$ level in $E$. grandis wastes (via fertilization or intercropping) offers better conditions for bacterial growth in the litter. Lambais et al. (2006) noted that the structure of the microbial community can differ between the phyllosphere of individual plants, and that variation within a species is often due to variations in leaf age, location in the canopy, light conditions, and climate.

The PCA helped illustrate these differences in litter and soil. In both sampling periods, the $A$. mangium monoculture was situated far from the other plantation sites, being more strongly associated with $\mathrm{C}$ and $\mathrm{N}$ soil contents, litter $\mathrm{N}$ content, MBNSO, and lignin content (Figure $3 \mathrm{a}, \mathrm{b}$ ). When $A$. mangium was planted together with $E$. grandis, however, its chemical and microbiological properties in soil and litter differed from those in monoculture. This also appears to be the case for $E$. grandis in the intercropped plantation, situated far from the $E$. grandis monocultures (EN and $\mathrm{E})$.

The deposition of fresh plant material can help reduce variation in temperature and moisture, which are key factors for the microbial establishment and development and have important implications for soil health and nutrient cycling (Nogueira et al., 2006; Sinha et al., 2009). Microclimate, rhizosphere effects, and plant species play crucial roles in modulating 

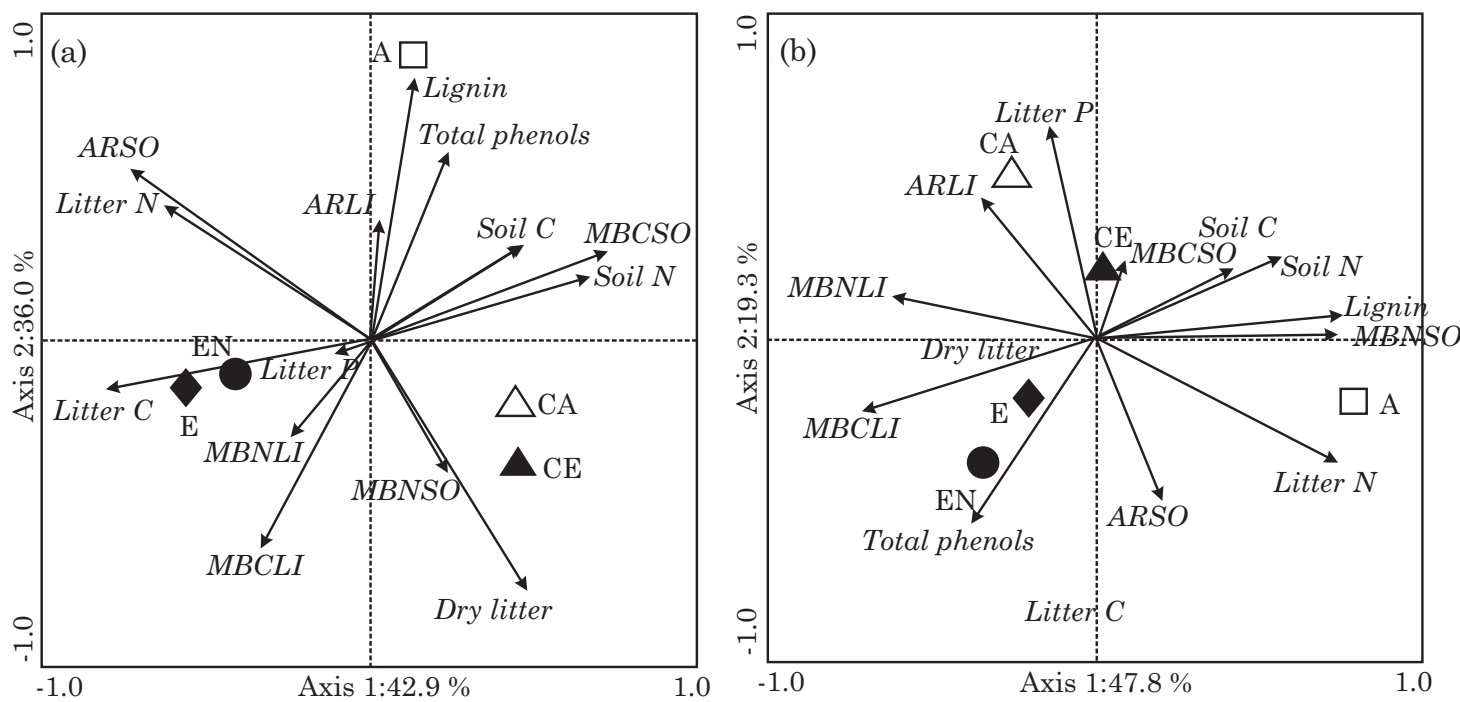

Figure 3. Principal component analysis of the chemical and microbiological variables of soils and litter seven (a) and 14 months after planting (b). (A) A. mangium monoculture; (E) E. grandis monoculture; (EN) $E$. grandis monoculture with $\mathrm{N}$ fertilizer; (CA) mixed plantation (at the stem base of $A$. mangium); (CE) mixed plantation (at the stem base of $\boldsymbol{E}$. grandis). ARSO (accumulated respiration of the soil); ARLI (accumulated respiration of the litter); MBCSO and MBNSO (Microbial biomass C and N of soil, respectively); MBCLI and MBNLI (Microbial biomass $\mathrm{C}$ and $\mathrm{N}$ of litter, respectively).

Table 2. Total fungi and bacteria quantified in the soils and litter of mixed and pure plantations of Eucalyptus grandis and Acacia mangium seven and 14 months after planting

\begin{tabular}{|c|c|c|c|c|}
\hline \multirow{2}{*}{ Planting/month } & \multicolumn{2}{|c|}{ Total fungi } & \multicolumn{2}{|c|}{ Total bacteria } \\
\hline & 7 months & 14 months & 7 months & 14 months \\
\hline & \multicolumn{4}{|c|}{$\log$ MPN g $^{-1}$} \\
\hline & \multicolumn{4}{|c|}{ Litter } \\
\hline $\mathrm{EN}$ & $6.6(0.3) \mathrm{b}$ & $12.0(0.4) \mathrm{c}$ & $8.6(0.2) \mathrm{b}$ & $13.9(0.1) \mathrm{a}$ \\
\hline $\mathrm{A}$ & $6.9(0.3) \mathrm{b}$ & $11.8(0.3) \mathrm{d}$ & $8.2(0.1) \mathrm{c}$ & $12.8(0.1) \mathrm{c}$ \\
\hline $\mathrm{E}$ & $6.7(0.3) \mathrm{b}$ & $12.5(0.4) \mathrm{b}$ & $8.5(0.1) \mathrm{b}$ & $12.9(0.1) \mathrm{c}$ \\
\hline $\mathrm{CA}$ & $7.2(0.3) \mathrm{a}$ & $11.7(0.4) \mathrm{d}$ & $9.2(0.2) \mathrm{a}$ & $13.2(0.2) \mathrm{b}$ \\
\hline $\mathrm{CE}$ & $6.7(0.4) \mathrm{b}$ & $12.9(0.3) \mathrm{a}$ & $8.5(0.3) \mathrm{b}$ & $13.8(0.1) \mathrm{a}$ \\
\hline $\mathrm{CV}(\%)^{(1)}$ & 3.5 & 1.3 & 2.9 & 2.6 \\
\hline Period & & & & \\
\hline Period $\mathrm{x}$ treatment & & & & \\
\hline \multirow[t]{2}{*}{$\mathrm{CV}(\%)$} & & & & \\
\hline & \multicolumn{4}{|c|}{ Soil } \\
\hline $\mathrm{EN}$ & $5.0(0.2) \mathrm{ab}$ & $5.7(0.2) \mathrm{a}$ & $6.3(0.2) \mathrm{a}$ & $7.1(0.2) \mathrm{d}$ \\
\hline $\mathrm{A}$ & $5.3(0.2) \mathrm{a}$ & $5.4(0.1) \mathrm{b}$ & $6.5(0.2) \mathrm{a}$ & $8.1(0.2) \mathrm{a}$ \\
\hline $\mathrm{E}$ & $4.8(0.2) \mathrm{bc}$ & $5.7(0.2) \mathrm{a}$ & $6.3(0.2) \mathrm{a}$ & $7.7(0.2) \mathrm{c}$ \\
\hline $\mathrm{CA}$ & $4.7(0.2) \mathrm{c}$ & $5.6(0.2) \mathrm{ab}$ & $6.2(0.3) \mathrm{a}$ & $7.9(0.3) \mathrm{b}$ \\
\hline $\mathrm{CE}$ & $5.2(0.2) \mathrm{a}$ & $5.8(0.1) \mathrm{a}$ & $6.4(0.3) \mathrm{a}$ & $7.8(0.3) \mathrm{b}$ \\
\hline $\mathrm{CV}(\%)^{(1)}$ & 6.0 & 4.6 & 4.1 & 1.1 \\
\hline Period & & & & \\
\hline Period $\mathrm{x}$ treatment & & & & \\
\hline $\mathrm{CV}(\%)$ & & & & \\
\hline
\end{tabular}

(A) A. mangium monoculture; (E) E. grandis monoculture; (EN) E. grandis monoculture with nitrogen fertilizer; (CA) mixed plantation (at the base of A. mangium); (CE) mixed plantation (at the base of $E$. grandis); CV: Coefficient of variation; * p $>0.001$; values followed by the same letter within a column are not significantly different according to Duncan's test at $5 \%$. 
microbial activity and biomass in soil. Microbial biomass in litter appears to be an especially large sink for $\mathrm{C}$ and nutrients at these sites, especially where there are residues of both $E$. grandis and $A$. mangium. The intercropped plantation stimulated microbial activity in litter, increased MBCLI, and stimulated P cycling due to the greater $\mathrm{P}$ content in litter after leaf drop.

\section{CONCLUSIONS}

1. Data on the chemical and microbiological properties of soil and litter offer evidence that intercropping $E$. grandis and $A$. mangium stimulates microbial activity.

2. Microbial biomass $\mathrm{N}$ in litter (MBNLI) represented a large $\mathrm{N}$ pool in all treatments, especially after leaf drop in the EN and CA treatments.

3 . The microbiological and chemical properties of litter were more sensitive than those of soil to the plant developmental stage (seven and 14 months after planting) and leaf drop.

\section{ACKNOWLEDGEMENTS}

We thank FAPESP for financing this research (Projects no. 2009/17525-6 and no. 2010/16623-9), and the teams of the Experimental Station of Forestry Science of Itatinga and the Soil Microbiology Laboratory of the "Luiz de Queiroz" School of Agriculture for their help in carrying out the project. D. Bini was supported by a doctoral grant (no. 140893/ 2011-3) and E. J. B. N. Cardoso by a productivity grant (no. 307563/2009-0) of the CNPq.

\section{LITERATURE CITED}

ALEF, K. Soil respiration. In: ALEF, K. \& NANNIPIERI, P., eds. Methods in applied soil microbiology and biochemistry. London, Academic Press, 1995. p.214-219.

ANDERSON, J.D. \& INGRAM, J.S.I. Tropical soil biology and fertility: A handbook of methods. 2.ed. Wallingford, CAB International, 1996. p.171.

ANDERSSON, M.; KJOLLER, A. \& STRUWE, S. Microbial enzyme activities in leaf litter, humus and mineral soil layers of European forests. Soil Biol. Biochem., 36:1527-1537, 2004.

ARAÚJO, C.V.M.; ALVES, L.J.; SANTOS, O.M. \& ALVES, J.M. Arbuscular mycorrhiza in Eucalyptus cloeziana F. Muell plantations in the north littoral of Bahia, Brazil. Acta Bot. Bras., 18:513-520, 2004.

AUER, C.G.; GHIZELINI, A.M. \& PIMENTEL, I.D. Decomposição fúngica de acículas em plantios de Pinus. Pesq. Flor. Bras., 54:127-138, 2007.
BADIANE, N.N.Y.; CHOTTE J.L.; PATE, E.; MASSE, D. \& ROULAND, C. Use of soil enzyme activities to monitor soil quality in natural and improved fallows in semi-arid tropical regions. Appl. Soil Ecol., 18:229-238, 2001.

BARRETO, P.A.B.; GAMA-RODRIGUES, E.F.; GAMARODRIGUES, A.C.; BARROS, N.F. \& FONSECA, S. Atividade microbiana, carbono e nitrogênio da biomassa microbiana em plantações de eucalipto, em sequência de idades. R. Bras. Ci. Solo, 1:611-619, 2008.

BOUILLET, J.P.; LACLAU, J.P.; GONÇALVES, J.L.; MOREIRA, M.Z.; TRIVELIN, P.C.O.; JOURDAN, C.; SILVA, E.V.; PICCOLO, M.C.; TSAI, S.M. \& GALIANA, A. Mixed-species plantations of Acacia mangium and Eucalyptus grandis in Brazil. 2: Nitrogen accumulation in the stands and biological $\mathrm{N}_{2}$ fixation. For. Ecol. Manage., 255:3918-3930, 2008.

BRANDÃO, E.M. Os componentes da comunidade microbiana do solo. In: CARDOSO, E.J.B.N.; TSAI, S.M. \& NEVES, M.C.P., eds. Microbiologia do solo. Campinas, Sociedade Brasileira de Ciência do Solo, 1992. p.1-16.

CARVALHO, A.M.X.; VALE, H.M.M.; FERREIRA, E.M.; CORDERO, A.F.P.; BARROS, N.F. \& COSTA, D. Atividade microbiana de solo e serapilheira em áreas povoadas com Pinus elliottii e Terminalia ivorensis. R. Bras. Ci. Solo, 32:2709-2716, 2008.

DICK, W.A. \& TABATABAI, M.A. Significance and potential uses of soil enzymes. In: BLAIN, F.J., ed. Soil microbial ecology application in agricultural and environmental management. New York: Marcel Dekker, 1993. p.95-127.

FORRESTER, D.I.; BAUHUS, J.; COWIE, A.L. \& VANCLAY, J.K. Mixed-species plantations of Eucalyptus with nitrogen-fixing trees: A review. For. Ecol. Manage., 233:211-230, 2006.

GAMA-RODRIGUES, E.F.; BARROS, N.F.; VIANA, A.P. \& SANTOS, G.A. Alterações na biomassa e na atividade microbiana da serapilheira e do solo, em decorrência da substituição de cobertura florestal nativa por plantações de eucalipto, em diferentes sítios da região sudeste do Brasil. R. Bras. Ci. Solo, 4:1489-1499, 2008.

GAMA-RODRIGUES, A.C. Ciclagem de nutrientes por espécies florestais em povoamentos puros e mistos, em solos de tabuleiro da Bahia, Brasil. Viçosa, MG, Universidade Federal de Viçosa, 1997. 107p. (Tese de Doutorado)

GONÇALVES, J.L.M.; STAPE, J.L.; LACLAU, J.P.; SMETHURST, P. \& GAVA, J.L. Silvicultural effects on the productivity and wood quality of Eucalyptus plantations. For. Ecol. Manage., 193:45-61, 2004.

GONÇALVES, J.L.M.; STAPE, J.L.; WICHERT, M.C.P. \& GAVA, J.L. Manejo de resíduos vegetais e preparo de solo. In: GONÇALVES, J.L.M \& STAPE, J.L., eds. Conservação e cultivo de solos para plantações florestais. Piracicaba, Instituto de Pesquisas e Estudos Florestais, 2002, p. 131-204.

HECTOR, A.; BEALE, A.J.; MINNS, A.; OTWAY, S.J. \& LAWTON, J.H. Consequences of the reduction of plant diversity for litter decomposition: Effects through litter quality and microenvironment. Oikos, 90:357-371, 2000. 
JAHNEL, M.C.; CARDOSO, E.J.B.N. \& DIAS, C.T.S. Determinação do número mais provável de microrganismos do solo pelo método de plaqueamento por gotas. R. Bras. Ci. Solo, 23:553-559, 1999.

KASCHUK, G.; ALBERTON, O. \& HUNGRIA, M. Three decades of soil microbial biomass studies in Brazilian ecosystems: Lessons learned about soil quality and indications for improving sustainability. Soil Biol. Biochem., 42:1-13, 2010.

KNORR, M.; FREY, S.D. \& CURTIS, P.S. Nitrogen additions and litter decomposition: A meta-analysis. Ecology, 86:3252-3257, 2005.

LACLAU, J.P.; BOUILLET, J.P.; GONÇALVES, J.L.M.; SILVA, E.V.; JOURDAN, C.; CUNHA, M.C.S.; MOREIRA, M.R.; SAINT-ANDRÉ, L.; MAQUÈRE, V.; NOUVELLON, Y. \& RANGER, J. Mixed-species plantations of Acacia mangium and Eucalyptus grandis in Brazil. Growth dynamics and aboveground net primary production. For. Ecol. Manage., 255:3905-3917, 2008.

LAMBAIS, M.R.; CROWLEY, D.E.; CURY, J.C.; BÜLL, R.C. \& RODRIGUES, R.R. Bacterial diversity in tree canopies of the Atlantic forest. Science, 312:1917, 2006.

LEVIN, D.A. Plant phenolics: An ecological perspective. Am. Natur., 105:157-181, 1971.

MONTEIRO, M.T. \& GAMA-RODRIGUES, E.F. Carbono, nitrogênio e atividade da biomassa microbiana em diferentes estruturas de serapilheira de uma floresta natural. R. Bras. Ci. Solo, 28:819-826, 2004.

MURPHY, J. \& RILEY, J.P. A modified single solution method for the determination of phosphate in natural waters. Anal. Chim. Acta, 27:31-36, 1962.

NOGUEIRA, M.A.; ALBINO, U.B.; BRANDÃO-JÚNIOR, O.; BRAUN, G.; CRUZ, M.F.; DIAS, B.A.; DUARTE, R.T.D.; GIOPPIO, N.M.R.; MENNA, P.; ORLANDI, J.M.; RAIMAN, M.P.; RAMPAZO, L.G.L.; SANTOS, M.A.; SILVA, M.E.Z.; VIEIRA, F.P.; TOREZAN, J.M.D.; HUNGRIA, M. \& ANDRADE, G. Promising indicators for assessment of agroecosystems alteration among natural, reforested and agricultural land use in southern Brazil. Agric. Ecosyst. Environ., 115:237-247, 2006.

NORBY, R.J. \& COTRUFO, M.F. A question of litter quality. Nature, 396:12-13, 1998.
NOUVELLON, Y.; LACLAU, J.P.; EPRON, D.; LE MAIRE, G.; BONNEFOND, J.M.; GONÇALVES, J.L.M. \& BOUILLET, J.P. Production and carbon allocation in monocultures and mixed-species plantations of Eucalyptus grandis and Acacia mangium in Brazil. Tree Physiol., 32:680-695, 2012.

PRESCOTT, C.E. Litter decomposition: What controls it and how can we alter it to sequester more carbon in forest soils? Biogeochemistry, 101:133-149, 2010.

SINHA, S.; MASTO, R.E.; RAM, L.C.; SELVI, V.A.; SRIVASTAVA, N.K.; TRIPATHI, R.C. \& GEORGE, J. Rhizosphere soil microbial index of tree species in a coal mining ecosystem. Soil Biol. Biochem., 41:1824-1832, 2009.

SMITH, V.C. \& BRADFORD, M.A. Do non-additive effects on decomposition in litter-mix experiments result from differences in resource quality between litters? Oikos, 2:235-242, 2003.

SWIFT, M.J.; HEAL, O.W. \& ANDERSON, J.M. Decomposition in terrestrial ecosystems. Berkeley, University of California Press, 1979. 372p.

TAYLOR, B.R.; PARKINSON, D. \& PARSONS, W.F.J. Nitrogen and lignin content as predictors of litter decay rates: a microcosm test. Ecology, 70:97-104, 1989.

TER BRAAK, C.J.F. \& SMILAUER, P. CANOCO Reference manual and user's guide to Canoco for Windows: Software for Canonical Community Ordination (Version 4.0). New York, Microcomputer Power, 2002. 353p.

van SOEST, P. \& WINE, R.H. Development of a comprehensive system of feed analysis and its applications to forages. J. Assoc. Agric. Chem., 51:780-785, 1968.

VANCE, E.D.; BROOKES, P.C. \& JENKINSON, D.S. An extraction method for measuring soil microbial biomass C. Soil Biol. Biochem., 19:703-707, 1987.

VOIGTLAENDER, M.; LACLAU, J.P.; GONÇALVES, J.L.D.M.; PICCOLO, M.D.C.; MOREIRA, M.Z.; NOUVELLON, Y.; RANGER, J. \& BOUILLET, J.P. Introducing Acacia mangium trees in Eucalyptus grandis plantations: Consequences for soil organic matter stocks and nitrogen mineralization. Plant Soil, 352:99-111, 2012.

WEST, G.G.; DEAN, M.G. \& PERCIVAL, N.S. The productivity of Maku lotus as a forest understorey. Proc. New Zealand Grass. Assoc., 53:169-173, 1991. 